\section{Effect of radiotherapy after mastectomy and axillary surgery on 10-year recurrence and 20-year breast cancer mortality: meta-analysis of individual patient data for 8135 women in 22 randomised trials}

EBCTCG (Early Breast Cancer Trialists' Collaborative Group)

Lancet 2014; 383: 2127-2135

W dotychczasowych metaanalizach wykazano obniżenie ryzyka nawrotu oraz umieralności po zastosowaniu pooperacyjnej radioterapii u chorych na raka piersi z przerzutami do pachowych węzłów chłonnych. Kliniczna korzyść w grupie chorych z przerzutami do 1-3 węzłów pozostaje niepewna. Oceniono rolę radioterapii w tej grupie chorych, poddanych mastektomii i pachowej limfadenektomii.

Metody. Przeprowadzono metaanalizę danych 8135 chorych włączonych do 22 badań klinicznych w latach 1964-1986, które przydzielano losowo do pooperacyjnej radioterapii na obszar ściany klatki piersiowej oraz regionalnego spływu chłonnego lub do wyłącznego leczenia operacyjnego - mastektomii z pachową limfadenektomią. Czas obserwacji dotyczącej nawrotów wyniósł 10 lat, natomiast czas przeżycia obserwowano do 1 stycznia 2009 roku. Analizy stratyfikowano względem badania, roku prowadzonej obserwacji, wieku chorej przy włączeniu do badania oraz stanu węzłów chłonnych w badaniu patomorfologicznym. Wyniki. 3786 chorych poddanych pachowej limfadenektomii (najmniejszy zakres limfadenektomii: Il poziom węzłów pachowych) podzielono na grupy: bez przerzutów w węzłach chłonnych, z przerzutami do $1-3$ lub $\geq 4$ węzłów chłonnych. Napromieniany obszar obejmował ścianę klatki piersiowej, okolicę nadobojczykową i/lub dół pachowy oraz zamostkowe węzły chłonne. W grupie 700 chorych z cechą No, poddanych pachowej limfadenektomii, zastosowanie radioterapii nie miało znamiennego wpływu na ryzyko wystąpienia miejscowo-regionalnego nawrotu (dwustronny poziom istotności [2p] > 0,1), jakiegokolwiek nawrotu (napromieniane vs nienapromieniane chore RR 1,06, 95\% $\mathrm{Cl} 0,76-1,48,2 p>0,1)$ ani zgonu z powodu raka piersi (RR $1,18,95 \% \mathrm{Cl} 0,89-1,55,2 p>0,1)$. W grupie 1314 chorych z przerzutami do 1-3 pachowych węzłów chłonnych, poddanych pachowej limfadenektomii, zastosowanie radioterapii zmniejszyło ryzyko miejscowo-regionalnego nawrotu $(2 \mathrm{p}<0,00001)$, jakiegokolwiek nawrotu (RR 0,68,95\% Cl $0,57-0,82,2 p=0,00006$ ) oraz zgonu z powodu raka piersi (RR 0,80,95\% Cl 0,67-0,95, 2p =0,01). U 1133 spośród 1314 chorych zastosowano leczenie systemowe (cyklofos- famid, metotreksat i fluorouracyl lub tamoksyfen). Również w tej grupie po zastosowaniu uzupełniającej radioterapii wykazano obniżenie ryzyka miejscowo-regionalnego nawrotu $(2 p<0,00001)$, jakiegokolwiek nawrotu (RR 0,67, 95\% $\mathrm{Cl} 0,55-0,82,2 \mathrm{p}=0,00009$ ) i zgonu z powodu raka piersi (RR $0,78,95 \% \mathrm{Cl} 0,64-0,94,2 p=0,01)$. W grupie 1772 chorych z przerzutami do $\geq 4$ węzłów chłonnych, poddanych pachowej limfadenektomii, zastosowanie radioterapii zmniejszyło ryzyko miejscowo-regionalnego nawrotu $(2 p<0,00001)$, jakiegokolwiek nawrotu (RR 0,79, 95\% Cl 0,69-0,90, $2 \mathrm{p}=0,0003)$ i zgonu z powodu raka piersi (RR $0,87,95 \% \mathrm{Cl}$ $0,77-0,99,2 p=0,04)$.

Wnioski. Zastosowanie radioterapii po mastektomii i pachowej limfadenektomii zmniejszało ryzyko nawrotu i zgonu z powodu raka piersi w grupie chorych z przerzutami do 1-3 pachowych węzłów chłonnych niezależnie od leczenia systemowego. Obecnie w wielu krajach chore na raka piersi są w mniejszym stopniu zagrożone nawrotem. Bezwzględna korzyść z uzupełniającej radioterapii może się wówczas okazać mniejsza, natomiast proporcjonalny zysk może być potencjalnie większy ze względu na bardziej skuteczne techniki radioterapii.

\section{Early palliative care for patients with advanced cancer: a cluster-randomised controlled trial}

Zimmermann C, Swami N, Krzyzanowska M i wsp. Lancet 2014; 383; 9930: 1721-1730

Jakość życia w zaawansowanym stadium choroby nowotworowej jest wyraźnie obniżona, a stan ten pogłębia się u schyłku życia. Oceniono wpływ wcześnie wdrożonej opieki paliatywnej na jakość życia chorych na zaawansowany nowotwór.

Metody. Badanie przeprowadzono w okresie od 1 grudnia 2006 roku do 28 lutego 2011 roku w Princess Margaret Cancer Centre (Toronto, ON, Kanada). 24 kliniki onkologiczne przydzielono losowo (w stosunku 1:1, stratyfikując względem liczby chorych leczonych w klinice oraz lokalizacji nowotworu [płuco - 4, przewód pokarmowy - 8, układ moczowo-płciowy - 4, pierś - 6, narząd rodny - 2]) do konsultacji i obserwacji (przynajmniej 1 raz w miesiącu) przez zespół opieki paliatywnej lub zespół standardowej opieki onkologicznej. Pełne zaślepienie podejmowanych interwencji było niemożliwe. Chorzy podpisali zgodę na uczestnictwo w danej grupie i nie byli informowani o istnieniu drugiej grupy. Kryteriami włączenia do badania były:zaawansowana 
choroba nowotworowa, stan sprawności 0-2 wg skali ECOG oraz oczekiwany czas przeżycia 6-24 miesięcy. Jakość życia (skala Functional Assessment of Chronic Illness Therapy-Spiritual Well-Being [FACIT-Sp] i skala Quality of Life at the End of Life [QUAL-E]), nasilenie objawów (skala Edmonton Symptom Assessment System [ESAS]), satysfakcję z opieki (FAMCARE-P16) oraz utrudnienia w zakresie klinicznego współdziałania (Cancer Rehabilitation Evaluation System Medical Interaction Subscale [CARES-MIS]) oceniano na początku badania oraz raz w miesiącu przez kolejne 4 miesiące. Głównym punktem końcowej oceny była zmiana punktacji w skali FACIT-Sp po 3 miesiącach. Wtórnymi punktami końcowej oceny były: zmiana punktacji w skali FACIT-Sp po 4 miesiącach i zmiana punktacji w pozostałych skalach po 3 i 4 miesiącach.

Wyniki. $U 461$ chorych wykonano pomiary na początku badania (228 - interwencja, 233 - kontrola), a u 393 chorych wykonano przynajmniej jeden pomiar w okresie obserwacji. Po 3 miesiącach odnotowano nieznamienną różnicę w punktacji w skali FACIT-Sp pomiędzy grupą badaną a kontrolną (3,56 punktu [95\% $\mathrm{Cl}-0,27$ do 7,40], $\mathrm{p}=0,07)$, znamienną różnicę w skali QUAL-E $(2,25[0,01$ do 4,49], $p=0,05)$ i FAMCARE-P16 (3,79 [1,74 do 5,85], p=0,0003), nie wykazano różnicy w punktacjach w skali ESAS $(-1,70$ [-5,26 do 1,87], $p=0,33)$ oraz CARES-MIS $(-0,66[-2,25$ do 0,94$], p=0,40)$. Po 4 miesiącach wykazano znamienne różnice punktacji we wszystkich skalach z wyjątkiem CARES-MIS. Różnice w wynikach potwierdziły większą skuteczność interwencji podjętych w grupie badanej.

Wnioski. Różnica w ocenie parametrów jakości życia w pierwotnym punkcie końcowej oceny była nieznamienna, jednak obiecujące wyniki badania uzasadniają wczesne wdrażanie paliatywnej opieki.

\section{Preoperative chemotherapy for non-small-cell lung cancer: a systematic review and meta-analysis of individual participant data}

NSCLC Meta-analysis Collaborative Group

Lancet 2014; 383: 1561-1571

Wyniki metaanaliz, oceniających dane poszczególnych uczestników badań, potwierdzają wydłużenie czasu przeżycia po zastosowaniu przedoperacyjnej chemioterapii u chorych na niedrobnokomórkowego raka płuca (NSCLC). Opracowano systematyczny przegląd oraz metaanalizę danych poszczególnych uczestników w celu oceny wpływu zastosowania przedoperacyjnej chemioterapii w grupie chorych na operacyjnego NSCLC.

Metody. W analizie uwzględniono badania rozpoczęte po styczniu 1965 roku. Uaktualnione dane poszczególnych uczestników były zbierane centralnie, sprawdzane oraz następnie analizowane. Dane z poszczególnych badań klinicznych z losowym doborem chorych (zarówno opublikowanych, jak i nieopublikowanych) zostały powiązane przy użyciu dwustopniowego modelu z efektem stałym. Pierwotny punkt końcowy - czas całkowitego przeżycia - określono jako czas od randomizacji do zgonu z jakiejkolwiek przyczyny, a żyjących chorych cenzurowano według daty ostatniej obserwacji. Wtórnymi punktami końcowymi były: czas wolny od nawrotu, czas do nawrotu miejscowo-regionalnego lub odległego, czas przeżycia zależny od przyczyny, częstość całkowitych i wszystkich resekcji oraz umieralność pooperacyjna. Wszystkie analizy przeprowadzono zgodnie z intencją leczenia.

Wyniki. Analiza 15 badań klinicznych z losowym doborem chorych (2 385 chorych) wykazała znamienne wydłużenie czasu przeżycia po zastosowaniu przedoperacyjnej chemioterapii ([HR] 0,87, 95\% Cl 0,78-0,96, p=0,007) oraz 13-procentowe obniżenie względnego ryzyka zgonu (nie wykazano różnic pomiędzy badaniami; $p=0,18, I^{2}=25 \%$ ). Wykazano bezwzględne zwiększenie udziału 5-letnich przeżyć o 5\% (z 40\% do 45\%). Schemat chemioterapii, częstość jej podawania, liczba leków cytostatycznych, rodzaj pochodnej platyny i zastosowanie pooperacyjnej radioterapii nie miały wpływu na czas przeżycia. Nie wyodrębniono jednoznacznie grupy chorych (uwzględniając wiek, płeć, stan sprawności, rozpoznanie histopatologiczne nowotworu, stopień zaawansowania), która odniosłaby szczególną korzyść z przedoperacyjnej chemioterapii. Czas wolny od nawrotu (HR 0,85, 95\% Cl 0,76-0,94, p=0,002) i czas do odległego nawrotu $(0,69,0,58-0,82, p<0,0001)$ były znamiennie dłuższe w grupie chorych poddanych przedoperacyjnej chemioterapii (większość chorych w stopniu zaawansowania klinicznego IB-IIIA). Czas do nawrotu miejscowo-regionalnego był nieznamiennie dłuższy w grupie chorych otrzymujących przedoperacyjną chemioterapię $(0,88,0,73-1,07, p=0,20)$. Wnioski. Wyniki analizy (opartej o dane $92 \%$ chorych przydzielonych losowo do leczenia, głównie w stopniu klinicznego zaawansowania IB-IIIA) wskazują, że zastosowanie przedoperacyjnej chemioterapii u chorych na operacyjnego NSCLC znamiennie wydłuża czas całkowitego przeżycia, czas do nawrotu odległego i czas wolny od nawrotu. Przedstawione dane wskazują, że przedoperacyjna chemioterapia jest istotną opcją leczenia dla większości z tej grupy chorych. Nie oceniono toksyczności zastosowanego leczenia.

\section{Trastuzumab emtansine versus treatment of physician's choice for pretreated HER2- -positive advanced breast cancer (TH3RESA): a randomised, open-label, phase 3 trial}

Krop I, Kim S, González-Martín A i wsp.

Lancet Oncol 2014; 15: 689-699

Możliwości leczenia chorych na nawrotowego lub uogólnionego raka piersi z progresją choroby po $\geq 2$ liniach leczenia celowanego anty-HER2 są ograniczone. Porównano skuteczność trastuzumabu z emtanzyną (koniugatu przeciwciała 
i leku cytostatycznego DM1) z leczeniem wybranym przez onkologa w tej grupie chorych.

Metody. Otwarte badanie III fazy z losowym doborem chorych prowadzono w ośrodkach onkologicznych w 22 krajach Europy, Ameryki Północnej i Południowej oraz Azji. Do badania włączono pełnoletnie chore w stanie sprawności 0-2 wg ECOG, z frakcją wyrzutową $\geq 50 \%$, z progresją zaawansowanego, HER2-dodatniego raka piersi, które otrzymały $\geq 2$ linii leczenia celowanego anty-HER2 (włączając trastuzumab i lapatynib) oraz chemioterapię z udziałem taksoidów. Chore przydzielano losowo w schemacie randomizacji blokowej (w stosunku 2:1) do trastuzumabu z emtanzyną (3,6 mg/kg dożylnie co $21 \mathrm{dni}$ ) lub leczenia wybranego przez onkologa. Chore stratyfikowano względem rejonu świata (USA vs Europa Zachodnia vs inne), liczby uprzednio zastosowanych schematów leczenia (2-3 vs > 3, z wyłączeniem monoterapii hormonalnej) oraz obecności przerzutów w narządach trzewnych (obecne vs nieobecne). Pierwotnymi punktami końcowymi były czas do progresji (PFS), oceniany przez badacza, i czas całkowitego przeżycia w populacji analizowanej zgodnie $z$ intencją leczenia. Przedstawiono ostateczną analizę PFS oraz pierwszą pośrednią analizę całkowitego przeżycia.

Wyniki. Od 14 września 2011 r. do 19 listopada 2012 roku przydzielono losowo 602 chore, w tym 404 do trastuzumabu z emtanzyną i 198 do leczenia wybranego przez onkologa. Do dnia zakończenia zbierania danych (11 lutego 2013) 44 chore przydzielone do leczenia wybranego przez onkologa rozpoczęły leczenie trastuzumabem z emtanzyną (cross-over). Progresję w grupie otrzymującej trastuzumab z emtanzyną stwierdzono po medianie czasu obserwacji 7,2 miesiąca (IQR 5,0-10,1 miesiąca) i 6,5 miesiąca (IQR $4,1-9,7)$ w grupie otrzymującej leczenie wybrane przez onkologa, u 219 (54\%) chorych leczonych trastuzumabem z emtanzyną oraz u 129 (65\%) chorych leczonych zgodnie $z$ wyborem onkologa. PFS był znamiennie dłuższy w grupie otrzymującej trastuzumab z emtanzyną w porównaniu z grupą otrzymującą leczenie wybrane przez onkologa (mediana 6,2 miesiąca [95\% Cl 5,59-6,87] vs 3,3 miesiąca $[2,89-4,14]$; stratyfikowany iloraz ryzyka [HR] 0,528 [0,422$-0,661] ; p<0,0001)$. Pośrednia analiza wykazała tendencję do wydłużenia czasu całkowitego przeżycia w grupie chorych otrzymujących trastuzumab z emtanzyną (stratyfikowany HR 0,552 [95\% Cl 0,36-0,826]; $\mathrm{p}=0,0034$ ), ale granica dla przerwania badania nie została przekroczona. W grupie chorych otrzymujących trastuzumab z emtanzyną odnotowano mniej działań niepożądanych $\geq 3$. stopnia w porównaniu z grupą poddaną leczeniu wybranemu przez onkologa (130 zdarzeń [32\%] u 403 chorych vs 80 zdarzeń [43\%] u 184 chorych). W grupie chorych otrzymujących leczenie wybrane przez onkologa w porównaniu z grupą leczoną trastuzumabem z emtanzyną częstszymi działaniami niepożądanymi w stopniu nasilenia $\geq 3$ były: neutropenia (10 [2\%] vs 29 [16\%]), biegunka (3 [<1\%] vs 8 [4\%]) i gorączka neutropeniczna (1 [< 1\%] vs 7 [4\%]). W grupie leczonej trastuzumabem zemtanzyną częstszym działaniem niepożądanym w stopniu nasilenia $\geq 3$ była małopłytkowość (19 [5\%] vs 3 [2\%]). U 74 chorych (18\%) leczonych trastuzumabem z emtanzyną i u 38 chorych (21\%) otrzymujących leczenie wybrane przez onkologa odnotowano ciężkie zdarzenia niepożądane.

Wnioski. U chorych na zaawansowanego, HER2-dodatniego raka piersi, uprzednio leczonych trastuzumabem i lapatynibem, trastuzumab z emtanzyną powinien być uważany za nowy standard leczenia.

\section{Ipilimumab versus placebo after radiotherapy in patients with metastatic castration- -resistant prostate cancer that had progressed after docetaxel chemotherapy (CA184-043): a multicentre, randomised, double-blind, phase 3 trial}

Kwona E, Drake C, Scher H i wsp.

Lancet Oncol 2014;15: 700-712

Ipilimumab jest ludzkim przeciwciałem monoklonalnym, które poprzez wiązanie antygenu 4. na komórkach cytotoksycznych limfocytów T pobudza przeciwnowotworową odpowiedź immunologiczną. Oceniono skuteczność ipilimumabu, stosowanego po radioterapii u chorych na uogólnionego, opornego na kastrację raka gruczołu krokowego z progresją po leczeniu docetakselem.

Metody. W wieloośrodkowym, podwójnie zaślepionym badaniu III fazy z randomizacją chorych z przynajmniej jednym przerzutem do kości w przebiegu opornego na kastrację raka gruczołu krokowego z progresją po leczeniu docetakselem przydzielono losowo w stosunku 1:1 do paliatywnej radioterapii na obszar zajętej przerzutem kości (8 Gy w pojedynczej frakcji), a następnie do ipilimumabu w dawce $10 \mathrm{mg} / \mathrm{kg}$ lub placebo, podawanych co 3 tygodnie, do 4 cykli. Chorzy, u których nie wystąpiła progresja, mogli kontynuować podtrzymujące leczenie ipilimumabem $w$ dawce $10 \mathrm{mg} / \mathrm{kg}$ lub placebo, podawanymi co 3 miesiące do wystąpienia progresji choroby, nieakceptowanej toksyczności lub zgonu. Chorych przydzielano losowo, wykorzystując algorytm minimizacji, i stratyfikowano względem stanu sprawności wg ECOG, stężenia fosfatazy alkalicznej, stężenia hemoglobiny oraz ośrodka. Pierwotnym punktem końcowym był czas całkowitego przeżycia oceniany zgodnie z intencją leczenia.

Wyniki. Od 26 maja 2009 do 15 lutego 2012 roku 799 chorych przydzielono losowo (399 do ipilimumabu i 400 do placebo) i ujęto w analizie zgodnej z intencją leczenia. Mediana czasu całkowitego przeżycia wyniosła 11,2 miesiąca (95\% Cl 9,5-12,7) w grupie otrzymującej ipilimumab i 10,0 miesiąca $(8,3-11,0)$ w grupie otrzymującej placebo (współczynnik ryzyka $[H R]$ 0,85, 0,72-1,00; $p=0,053)$. Ocena założenia 
proporcjonalnych współczynników ryzyka wykazała ich zaburzenie ( $p=0,0031)$. W cząstkowym modelu ryzyka wykazano zmienność współczynnika ryzyka w czasie: HR dla miesięcy $0-5$ wyniósł 1,46 (95\% Cl 1,10-1,95), dla miesięcy 5-12 wyniósł 0,65 $(0,50-0,85)$, a powyżej 12 miesięcy $-0,60(0,43-0,86)$. Najczęstszymi działaniami niepożądanymi w 3.-4. stopniu nasilenia były objawy immunologiczne, które wystąpiły u 101 chorych (26\%) otrzymujących ipilimumab i 11 chorych (3\%) otrzymujących placebo. Najczęstszymi działaniami niepożądanymi w 3.-4. stopniu nasilenia były: biegunka (64 [16\%] spośród 393 chorych w grupie otrzymującej ipilimumab vs 7 [2\%] spośród 396 w grupie otrzymującej placebo), zmęczenie (40 [11\%] vs 35 [9\%]), niedokrwistość (40 [10\%] vs 43 [11\%]) oraz zapalenie jelita grubego (18 [5\%] vs 0). Odnotowano 4 zgony (1\%) spowodowane toksycznym działaniem ipilimumabu.

Wnioski. Mimo iż w pierwotnej analizie nie wykazano znamiennej różnicy w czasie całkowitego przeżycia pomiędzy grupą otrzymującą ipilimumab a grupą otrzymującą placebo, stwierdzono cechy aktywności ipilimumabu uzasadniające dalsze badania.

\section{Effect of radium-223 dichloride on symptomatic skeletal events in patients with castration- -resistant prostate cancer and bone metastases: results from a phase 3 , double-blind, randomised trial}

Sartor O, Coleman R, Nilsson S i wsp.

Lancet Oncol 2014; 15: 738-746

Przerzuty do kości są częstą przyczyną zdarzeń kostnych u chorych na uogólnionego raka gruczołu krokowego opornego na kastrację. Dwuchlorek radu 223 oddziałuje selektywnie na przerzuty do kości poprzez charakteryzujące się krótkim zasięgiem wysokoenergetyczne cząstki a,. Porównano skuteczność radu-223 z placebo u chorych na opornego na kastrację raka gruczołu krokowego z przerzutami do kości.

Metody. Do podwójnie zaślepionego badania III fazy ALSYMPCA włączano chorych na objawowego raka gruczołu krokowego opornego na kastrację $z \geq 2$ przerzutami do kości, bez przerzutów trzewnych, otrzymujących najlepsze standardowe leczenie, którzy byli wcześniej leczeni docetakselem lub nie kwalifikowali się do tego leczenia. Chorych stratyfikowano względem leczenia docetakselem, wyjściowego stężenia całkowitej fosfatazy zasadowej oraz równoczesnego stosowania bisfosfonianów, a następnie przydzielano losowo (2:1) do 6 dożylnych comiesięcznych wstrzyknięć radu-223 (50 kBq/kg) lub placebo. Pierwotnym punktem końcowej oceny był czas całkowitego przeżycia, a wyniki już uprzednio opublikowano. W niniejszej analizie przedstawiono czas do pierwszego zdarzenia kostnego, określonego jako zastosowanie teleradioterapii w celu złagodzenia dolegliwości bólowych, lub pojawienie się nowego, objawowego złamania patologicznego, zespołu ucisku rdzenia kręgowego lub konieczność interwencji ortopedycznej spowodowana chorobą podstawową. Uwzględniano wyłącznie zdarzenia objawowe, a nie jedynie widoczne w kontrolnych badaniach obrazowych. Analizy statystyczne objawowych zdarzeń kostnych przeprowadzono zgodnie $z$ intencją leczenia.

Wyniki. Od 12 czerwca 2008 do 1 lutego 2011 roku do badania włączono 921 chorych; 614 chorych (67\%) przydzielono do radu-223, a 307 (33\%) do placebo. Objawowe zdarzenia kostne obserwowano u 202 spośród 614 chorych (33\%) w grupie chorych otrzymujących rad-223 oraz u 116 spośród 307 chorych (38\%) otrzymujących placebo. Czas do pierwszego objawowego zdarzenia kostnego był dłuższy w grupie chorych otrzymujących rad w porównaniu z otrzymującymi placebo (mediana 15,6 miesiąca [95\% Cl 13,5-18,0] vs 9,8 miesiąca $[7,3-23,7] ;[H R]=0,66,95 \% \mathrm{Cl} 0,52-0,83 ; p=0,00037)$. Ryzyko konieczności zastosowania teleradioterapii w celu złagodzenia bólu kostnego ( $\mathrm{HR} 0,67,95 \% \mathrm{Cl} 0,53-0,85)$ lub objawów zespołu ucisku rdzenia kręgowego ( $\mathrm{HR}=0,52,95 \%$ Cl0,29-0,93) było niższe w grupie chorych otrzymujących rad223 w porównaniu z otrzymującymi placebo. Zastosowanie radu-223 nie zmniejszało znamiennie ryzyka objawowych patologicznych złamań kości (HR 0,62, 95\% Cl 0,35-1,09) ani ryzyka interwencji ortopedycznej spowodowanej chorobą podstawową (HR 0,72, 95\% Cl 0,28-1,82).

Wnioski. Rad-223 należy rozważyć u chorych na opornego na kastrację raka gruczołu krokowego z przerzutami do kości.

\section{Benefits, harms, and costs for breast cancer screening after US implementation of digital mammography}

Stout NK, Lee SJ, Schechter CB i wsp.

J Natl Cancer Inst 2014; 106 (6): dju092

Mammografia cyfrowa ma — w porównaniu z mammografią analogową - wyższą czułość, ale niższą swoistość u kobiet

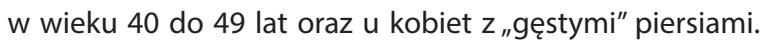
Mammografia cyfrowa zastąpiła analogową w większości placówek w Stanach Zjednoczonych, ale wpływ tej technologii na zdrowie populacji oraz koszty jest nieznany. Metody. Stosując 5 niezależnych modeli, porównano strategie przesiewowego badania cyfrowego wykonywanego co roku, co 2 lata lub zależnie od gęstości piersi u kobiet w wieku od 40 do 50 lat z mammografią analogową wykonywaną co 2 lata u kobiet w wieku od 50 do 74 lat oraz z grupą kobiet bez badań przesiewowych. Oceniano zachorowalność, liczbę wykonywanych badań zależnie od gęstości piersi, umieralność i liczbę lat życia z uwzględnieniem jego jakości, koszty badań przesiewowych oraz koszty leczenia. 
Wyniki. Dla 1000 kobiet poddanych badaniom przesiewowym co 2 lata w wieku od 50 do 74 lat zastąpienie analogowej mammografii mammografią cyfrową wiązało się z medianą dodatkowych 2 lat życia, uniknięciem 0,27 dodatkowych zgonów, 220 dodatkowymi fałszywie dodatnimi wynikami oraz kosztami wyższymi o 0,35 miliona \$. Dla pojedynczej kobiety przekłada się to na zysk zdrowia w wymiarze 0,73 dnia. Rozszerzenie badań przesiewowych przy użyciu mammografii cyfrowej wykonywanej co 2 lata na populację kobiet w wieku od 40 do 49 lat było kosztowo efektywne, chociaż wiązało się z obniżeniem jakości życia związanym z wykonywaniem badań przesiewowych oraz wynikami fałszywie dodatnimi. Corocznie wykonywanie badań przesiewowych z powodu gęstości piersi wiązało się z uzyskaniem podobnych wyników jak wykonywanie badań zależnie od wieku. Wykonywanie badań przesiewowych co roku może zwiększyć koszty do 5,26 milliona \$ na 1000 kobiet, częściowo ze względu na liczbę wykonywanych badań oraz fałszywie dodatnich wyników, i nie jest skuteczne ani kosztowo efektywne.

Wnioski. Zastąpienie analogowej mammografii mammografią cyfrową w badaniach przesiewowych w kierunku wykrywania raka piersi w Stanach Zjednoczonych zwiększyło całkowity koszt, przy niewielkiej dodatkowej korzyści zdrowotnej. Zastosowanie cyfrowej mammografii w badaniach przesiewowych u kobiet w wieku od 40 do 49 lat zależy od preferencji kobiet; należy uwzględnić możliwość uzyskania wyników fałszywie dodatnich.

\section{Impact of lung cancer screening results on smoking cessation}

Tammemägi MC, Berg CD, Riley TL i wsp.

J Natl Cancer Inst 2014; 106 (6): dju084

Programy badań przesiewowych w kierunku wykrywania raka płuca mogą wpływać na obniżenie częstości palenia wśród ich uczestników. Oceniono wpływ wyników badań przesiewowych na rzucenie palenia.

Metody. Dane uczestników badania Lung Screening Study w ramach National Lung Screening Trial (NLST; 2002-2009) wykorzystano do przygotowania wieloczynnikowych modeli liniowej regresji, przewidujących rzucenie palenia w ciągu roku u palaczy włączonych do badania $(n=15489$, wyłączając chorych, u których doszło do rozwoju raka płuca w czasie obserwacji). Oceniono związek pomiędzy wynikami badań przesiewowych a rzuceniem palenia w czasie badania. Wszystkie hipotezy testowano, stosując dwustronne wartości $P$.

Wnioski. Rzucenie palenia było silnie związane z liczbą nieprawidłowości obserwowanych w badaniach przesiewowych wykonanych w poprzednim roku ( $<<0,0001)$. Rzucenie palenia było bardziej prawdopodobne wśród uczestników badania, u których w poprzednim roku stwier- dzono znaczne nieprawidłowości, które nie wzbudzały podejrzenia raka płuca (iloraz szans $[\mathrm{OR}]=0,811 ; 95 \%$ przedział ufności $[\mathrm{Cl}]=0,722$ do 0,912; $\mathrm{p}<0,001)$, wzbudzały podejrzenie raka płuca, ale były stabilne w stosunku do poprzednich badań $(\mathrm{OR}=0,785 ; 95 \% \mathrm{Cl}=0,706$ do 0,$872 ; \mathrm{p}<0,001)$ lub wzbudzały podejrzenie raka płuca i były nowe lub zmieniły się w stosunku do poprzednich badań $(\mathrm{OR}=0,663 ; 95 \%$ $\mathrm{Cl}=0,607$ do 0,$724 ; \mathrm{p}<0,001$ ) w porównaniu z uczestnikami z prawidłowymi wynikami badań przesiewowych. Różnice w rzucaniu palenia utrzymywały się do 5 lat od ostatniego badania przesiewowego.

Wnioski. Rzucenie palenia wiązało się znamiennie z nieprawidłowościami wykrytymi w badaniach przesiewowych. Włączenie skutecznych programów rzucania palenia do badań przesiewowych powinno prowadzić do dalszego obniżenia związanej z paleniem zachorowalności i umieralności.

\section{Capecitabine and oksaliplatin in the preoperative multimodality treatment of rectal cancer: surgical end points from National Surgical Adjuvant Breast and Bowel Project Trial R-04}

O'Connell MJ, Colangelo LH, Beart RW i wsp. J Clin Oncol 2014; 32: 1927-1934

Cel. Nie jest znany najlepszy schemat chemioterapii stosowany w skojarzeniu z przedoperacyjną radioterapią (RT) u chorych na raka odbytnicy. W badaniu National Surgical Adjuvant Breast and Bowel Project R-04 porównano 4 schematy chemioterapii podawanej jednocześnie z RT.

Chorzy i metody. Chorych na raka odbytnicy w II lub III stopniu klinicznego zaawansowania zakwalifikowanych do przedoperacyjnej RT (45 Gy w 25 frakcjach przez 5 tygodni z dodatkiem [boost] 5,4 Gy do 10,8 Gy w 3 do 6 frakcji) przydzielano losowo do następujących schematów chemioterapii: ciągły dożylny wlew fluorouracylu (CVI FU $225 \mathrm{mg} / \mathrm{m}^{2}$ przez 5 dni w tygodniu) w połączeniu z oksaliplatyną lub bez oksaliplatyny $\left(50 \mathrm{mg} / \mathrm{m}^{2}\right.$ co tydzień przez 5 tygodni) lub do doustnej kapecytabiny $\left(825 \mathrm{mg} / \mathrm{m}^{2} 2\right.$ razy dziennie przez 5 dni w tygodniu) w połączeniu z oksaliplatyną lub bez oksaliplatyny $\left(50 \mathrm{mg} / \mathrm{m}^{2}\right.$ co tydzień przez 5 tygodni). Przed randomizacją chirurg oceniał w oparciu o badanie kliniczne, czy chory potencjalnie kwalifikuje się do zabiegu z zaoszczędzeniem zwieracza. Chirurgicznymi punktami końcowej oceny był udział całkowitych patologicznych odpowiedzi (pCR), zabieg z zaoszczędzeniem zwieracza oraz zmniejszenie stopnia zaawansowania, pozwalające na wykonanie zabiegu z zaoszczędzeniem zwieracza u chorych niekwalifikujących się do takiego zabiegu przed radiochemioterapią.

Wyniki. Od września 2004 do sierpnia 201 roku 1608 chorych przydzielono losowo do leczenia. Nie stwierdzono 
znamiennych różnic $w$ częstości $p C R$, w udziale zabiegów z zaoszczędzeniem zwieracza ani zmian w planowanym zabiegu operacyjnym pomiędzy grupami leczonymi CVI FU lub kapecytabiną, jak też pomiędzy grupami leczonymi oksaliplatyną lub bez udziału oksaliplatyny. U chorych leczonych z udziałem oksaliplatyny stwierdzono znamiennie więcej biegunek 3. lub 4. stopnia $(p<0,001)$.

Wnioski. Zastosowanie kapecytabiny w połączeniu z przedoperacyjną RT wiązało się z podobnymi udziałami pCR, zabiegów zzaoszczędzeniem zwieracza oraz zmniejszeniem stopnia zaawansowania, pozwalającym na wykonanie zabiegu z zaoszczędzeniem zwieracza w porównaniu z CVI FU. Dołączenie oksaliplatyny nie poprawiło wyników leczenia chirurgicznego i wiązało się z dodatkową znamienną toksycznością. Końcowe analizy dotyczące miejscowej kontroli guza, czasu do progresji oraz czasu całkowitego przeżycia zostaną przeprowadzone po wystąpieniu określonej przez protokół liczby zdarzeń.

\section{Impact of oophorectomy on cancer incidence and mortality in women with a BRCA1 or BRCA2 mutation}

Finch APM, Lubinski J, Møller P i wsp. J Clin Oncol 2014: 1547-1553

Cel. Celem badania było oszacowanie obniżenia ryzyka raka jajnika, raka jajowodu lub raka otrzewnej u kobiet z mutacją $B R C A 1$ lub BRCA2 w wyniku usunięcia jajników. Uwzględniono wiek wykonania zabiegu i oszacowano wpływ profilaktycznego usunięcia jajników na umieralność ze wszystkich przyczyn oraz na 5-letnie przeżycia chorych na raka jajnika lub otrzewnej.

Chore i metody. Kobiety z mutacją BRCA 1 lub BRCA2 określono na podstawie międzynarodowego rejestru. 5783 kobiety wypełniły kwestionariusz na początku badania oraz $\geq 1$ kwestionariusz podczas obserwacji. Kobiety obserwowano do czasu rozpoznania raka jajnika, jajowodu lub otrzewnej, zgonu lub daty ostatniej obserwacji. Współczynniki ryzyka (HRs) zachorowania na raka oraz umieralności ze wszystkich przyczyn związanych z usunięciem jajników oceniano, stosując zależne od czasu analizy przeżycia.

Wyniki. Po średniej czasu obserwacji 5,6 roku 186 kobiet zachorowało na raka jajnika ( $\mathrm{n}=132)$, jajowodu $(\mathrm{n}=22)$ lub otrzewnej $(n=32)$, spośród których 68 zmarło. HR dla zachorowania na raka jajnika, jajowodu lub otrzewnej związanego z usunięciem jajników wyniósł 0,20 (95\% Cl 0,13 do 0,30; $p<0,001)$. U kobiet, u których nie rozpoznano raka przed włączeniem do badania, HR dla zgonu z jakiejkolwiek przyczyny przed 70. rokiem życia związany z usunięciem jajników wyniósł 0,23 (95\% Cl 0,13 do 0,39; $\mathrm{p}<0,001)$.

Wnioski. Profilaktyczne usunięcie jajników wiąże się z 80-procentem obniżeniem ryzyka raka jajnika, jajowodu lub otrzewnej u nosicielek mutacji BRCA1 lub BRCA2 oraz z 77-procentowym obniżeniem umieralności ze wszystkich przyczyn.
Omitting radiotherapy in early positron emission tomography-negative stage I/II Hodgkin lymphoma is associated with an increased risk of early relapse: clinical results of the preplanned interim analysis of the randomized EORTC/LYSA/FIL H10 trial

Raemaekers JMM, André MPE, Federico M i wsp. J Clin Oncol 2014; 32: 1188-1194

Cel. Skojarzone leczenie stanowi standard u chorych na chłoniaka Hodgkina (HL) w stopniu zaawansowania I/II. Założono, że wczesne badanie pozytonową tomografią emisyjną (PET) może być zastosowane do dobrania odpowiedniego sposobu leczenia. Rozpoczęto badanie z randomizacją EORTC/LYSA/FIL Intergroup H10, oceniające, czy radioterapia na obszar zajętych węzłów chłonnych (involved-node radiotherapy IN-RT) może zostać pominięta bez wpływu na czas do progresji u chorych bez zmian w badaniu PET wykonanym po 2 cyklach ABVD (doksorubicyna, bleomycyna, winblastyna i dakarbazyna) w porównaniu ze standardowym leczeniem skojarzonym.

Chorzy i metody. Do badania włączano wcześniej nieleczonych chorych na HL w I/II stopniu zaawansowania, w wieku od 15 do 70 lat. Przedstawiono wyniki zaplanowanej wcześniej pośredniej analizy braku skuteczności, przeprowadzonej po 34 zdarzeniach w grupie z ujemnym wynikiem badania PET. Ponieważ testowanie braku skuteczności w badaniu o równoważności stosowanych sposobów leczenia odpowiada testowaniu hipotezy o braku różnicy, przeprowadzono jednostronny test przewagi.

Wnioski. Do analizy włączono 1137 chorych. W grupie z korzystnymi czynnikami u 85,8\% osób wynik wczesnego badania PET był ujemny (ramię standardowe — jedno zdarzenie vs ramię eksperymentalne -9 zdarzeń). W grupie z niekorzystnymi czynnikami u 74,8\% wynik wczesnego badania PET był ujemny (ramię standardowe - 7 zdarzeń vs ramię eksperymentalne - 16 zdarzeń). Niezależna komisja monitorowania danych stwierdziła, że uzyskanie nie gorszych wyników w ramieniu badanym w końcowych wynikach jest mało prawdopodobne, i doradziła zakończenie randomizacji w grupie chorych $z$ ujemnym wczesnym badaniem PET.

Wnioski. Na podstawie niniejszej analizy skojarzone leczenie z udziałem radioterapii wiązało się z mniejszą liczbą wczesnych progresji u chorych na HL w I/II stopniu zaawansowania, aczkolwiek wczesne wyniki leczenia były bardzo dobre w obu ramionach. Analiza końcowych wyników leczenia wykaże, czy niniejsze wyniki nie zmienią się po dłuższym czasie obserwacji.

Opracowali:

Dr n. med. Anna Kowalczyk

Dr n. med. Ewa Szutowicz

Lek. med. Anna Wrona

Dr n. med. Krzysztof Konopa 